\title{
Effect of Rejuvenation Pruning and Nitrogen Levels on Leaf Nutrient Status of Old and Senile Apricot (Prunus armeniaca L.) cv. New Castle Trees
}

\author{
R. Thokchom*, D.P. Sharma and K.K. Thakur \\ Department of Fruit Science, Dr. Y.S. Parmar University of Horticulture and Forestry, \\ Nauni, Solan (H.P)-173230, India
}

\section{A B S T R A C T}

\begin{tabular}{|l|}
\hline K e y w o r d s \\
$\begin{array}{l}\text { Senile, Apricot, } \\
\text { Rejuvenation, } \\
\text { Pruning, Nitrogen and } \\
\text { leaf nutrient }\end{array}$ \\
\hline Article Info \\
\hline $\begin{array}{l}\text { Accepted: } \\
\text { 16 December } 2017 \\
\text { Available Online: } \\
\text { 10 January } 2018\end{array}$ \\
\hline
\end{tabular}

Keywords

Senile, Aprico

Pruning, Nitrogen and leaf nutrient

\section{Introduction}

Apricot (Prunus armeniaca L.) locally known as 'Khumani' is a commercial fruit crop of mid hills and dry temperate regions of India. It is a small deciduous fruit tree of Rosaceae family native to China. Fruit is a rich source of vitamin A and C (Lee and Kader, 2000), potassium, phosphorus, calcium, magnesium, iron and selenium (Munzuroglu et al., 2003 and Ali et al., 2011); while sodium, manganese, zinc and copper are present in small amounts (USDA, 2005). In India, among the stone fruits, apricot ranks next only to plum and peach with an area of 5000 ha and production of 13,999 tonnes (FAO, 2014). In Himachal Pradesh, among the stone fruits, it also ranks next only to plum and peach with an area of 3444 ha and production of 3706 MT (Anonymous 2010). In Himachal Pradesh, apricot is cultivated extensively in Solan, Shimla, Sirmour, Chamba and Kinnaur districts. Out of the various apricot cultivars, New Castle' has a potential in the mid hills and valley areas of Himachal Pradesh because it has low chilling requirement and ripens in the end of May when no other fresh fruit is available in the market. Despite congenial agro-climatic conditions in the mid hills for the apricot production, a declining trend in its 
production and fruit quality has been observed during the last two decades. This is because most of the apricot plantations have become old and senile. The normal tree growth, productivity and quality of fruits of such senile orchards are being declining due to nutritional imbalances of soil and leaf nutrients status, which are caused by poor management practices as most of the farmers do not pruned and apply manures and fertilizers in the orchards. Milosevic and Milosevic, (2013) reported poor soil physicochemical characteristics are high problem in apricot orchard. Rejuvenation with special attention to pruning and fertilization has been found to be cost effective and is beneficial to the farmers rather than re-plantation of the new trees. Many workers had reported significant effect of pruning and nitrogen fertilization to improve the nutritional imbalances of soil and leaf nutrients status. Cassman et al., (2002) reported that plant nutrient availability and uptake ability in soil can be enhanced by the overall nitrogen balance and on the amount of soil nitrogen reserves. While Naik and Babu (2005) reported that increase in the nutrient status of the leaves in guava would have been due to enhanced invigorating effect of pruning severity on the absorption of mineral content by the plants which could have increased the leaf nutrient status of the plant. Keeping in view these problems, the proposed investigation was carried out to study the effect of rejuvenation treatment on leaf nutrient content of declining apricot trees rather than re-plantation.

\section{Materials and Methods}

A field trial was carried out in the experimental orchard of Department of Fruit Science, Dr. Yashwant Singh Parmar University of Horticulture and Forestry, Nauni, Solan, (H.P.) during the year 2011 to 2014. The experiment was laid out in a randomized block design comprising of ten treatment combinations including three pruning intensities viz., Heading back of scaffolds to 20, 40 and $60 \%$ each with three levels of nitrogen (500, 625 and $750 \mathrm{~g}$, respectively) along with control (Heading back at secondary branches level $+500 \mathrm{~g}$ Nitrogen), and with three replications. The experimental site was located at an elevation of $1250 \mathrm{~m}$ above mean sea level at $30^{\circ} 51^{\prime} \mathrm{N}$ latitude and $76^{\circ} 11^{\prime} \mathrm{E}$ longitude, representing sub-temperate, sub-humid mid hill zone of Himachal Pradesh. The soil is mountainous sandy loam soil with the properties as in data in Table 1.

The present studies were conducted on 25years old New Castle apricot trees raised on wild apricot rootstock spaced at $5 \times 5 \mathrm{~m}$ and trained to "Modified central leader" system. Rejuvenation pruning was done on selected trees in dormant season during the first week of February, in 2011 while in January 2012, 2013 and 2014 only the corrective pruning was uniformly carried out in all the experimental plants.

\section{Treatment combinations}

$\mathrm{T}_{1}=$ Heading back of scaffolds $(20 \%)+500 \mathrm{~g}$ $\mathrm{N}$,

$\mathrm{T}_{2}=$ Heading back of scaffolds $(20 \%)+625 \mathrm{~g}$ $\mathrm{N}$,

$\mathrm{T}_{3}=$ Heading back of scaffolds $(20 \%)+750 \mathrm{~g}$ $\mathrm{N}$,

$\mathrm{T}_{4}=$ Heading back of scaffolds $(40 \%)+500 \mathrm{~g}$ $\mathrm{N}$,

$\mathrm{T}_{5}=$ Heading back of scaffolds $(40 \%)+625 \mathrm{~g}$ $\mathrm{N}$

$\mathrm{T}_{6}=$ Heading back of scaffolds $(40 \%)+750 \mathrm{~g}$ $\mathrm{N}$

$\mathrm{T}_{7}=$ Heading back of scaffolds $(60 \%)+500 \mathrm{~g}$ $\mathrm{N}$,

$\mathrm{T}_{8}=$ Heading back of scaffolds $(60 \%)+625 \mathrm{~g}$ $\mathrm{N}$,

$\mathrm{T}_{9}=$ Heading back of scaffolds $(60 \%)+750 \mathrm{~g}$ $\mathrm{N}$ and 
$\mathrm{T}_{10}$ (control) $=$ Heading back at secondary branches level $+500 \mathrm{~g} \mathrm{~N}$.

Standard recommended doses of FYM, phosphorus and potassium were applied in all experimental trees in all the years.

Post analysis of orchard soil samples were done in 2011 and 2013 respectively to compute the mechanical and chemical characteristics status of soil to verify the effect of treatments and values are expressed in Table 1. Soil samples representing $0-45 \mathrm{~cm}$ depth were collected from four sites of each experimental tree basin during first week of February 2011 \& 2013. The samples were dried in shade, grounded, passed through 2 $\mathrm{mm}$ sieve and stored in cloth bags. The soil samples were analysed for bulk density and field capacity by standard procedure lay out by Kanwar and Chopra (1976). The chemical analysis of soil $\mathrm{pH}$ and electrical conductivity was determined by $1: 2$ or $1: 5$ soil water suspension methods using digital $\mathrm{pH}$ meter and conductivity meter, respectively, as described by Jackson (1973). Organic carbon was extracted according to the Chromic acid titration method, given by Walkely and Black (1934). The available macronutrient status i.e., $\mathrm{N}, \mathrm{P}$ and $\mathrm{K}$ content of orchard soils were determined according to the standard methods laid down by Subbiah and Asija (1956); Olsen et al., (1954); and Merwin and Peech (1951), accordingly.

For plant nutrients analysis, leaf samples were collected from the middle of the current season's growth all around the periphery of the tree, as recommended by Kenworthy (1964), in the month of July each year during investigation. The handling and preparation of samples were done in accordance with procedure given by Chapman (1964). The digestion of leaf samples for various nutrient elements was done in diacid mixture (nitric acid: perchloric acid in the ratio of 4:1). A separate digestion was carried for nitrogen estimation using concentrated sulphuric acid and digestion mixture as suggested by Jackson (1967). Analysis for various nutrient elements viz., 'N' was done by micro Kjeldahl method (A.O.A.C., 1980); 'P' by phosphor-molybdovanadate method (Jackson 1973) and 'K', 'Zn', 'Fe', 'Mn' and 'Cu' were determined on Atomic Absorption Spectrophotometer Element AS AAS4141 whereas for ' $\mathrm{Ca}$ ' and 'Mg' procedure layout by David (1960) and Fishman (1966) was followed. Data were subjected to one-way analysis of variance (ANOVA) as suggested by (Gomez and Gomez, 1984); and to mean separation with the Fisher's Least Significant Differences (LSD) test with $\mathrm{P} \leq 0.05$, using the statistical analysis program (SPSS).

\section{Results and Discussion}

\section{Effect on macro nutrient content of the leaf}

The perusal of the data given in Table 2 reveals that heavy pruning treatment along with increased dose of nitrogen influenced leaf $\mathrm{N}$ content significantly in pooled mean of 2011 to 2014. Highest leaf N (2.89\%) content was recorded in $\mathrm{T}_{9}$. Whereas, the lowest leaf $\mathrm{N}(2.56 \%)$ content was observed in $\mathrm{T}_{10}$. Increase in $\mathrm{N}$ content of the leaf with increase dose of $\mathrm{N}$ might be due to highly mobile nature of $\mathrm{N}$ in soil which efficiently translocated and accumulated in the leaves under abundant supply from the soil. In accordance to the above results Sud and Butani (1994) and Milosevic et al., (2013) reported that $\mathrm{N}$ uptake in apricot appears to increase with increasing $\mathrm{N}$ fertiliser rate. High $\mathrm{N}$ content in heavily pruned trees may be due to low yield/tree and less overall accumulation of dry matter in the leaves or pruning increased the synthesis of auxin and gibberellins in the above ground parts of tree which might promote the development of vascular system and activate nutrient transport 
in the remaining leaves and branches in apricot. Cheng and Raba (2009) recorded higher leaf nitrogen in heavily pruned apple trees.

Minimum pruning intensity and lower dose of $\mathrm{N}$ significantly increased the leaf $\mathrm{P}$ content in pooled mean of 2011 to 2014 (Table 2). Maximum leaf $\mathrm{P}(0.239 \%)$ content was recorded in $\mathrm{T}_{1}$ whereas the minimum leaf $\mathrm{P}$ $(0.207 \%)$ content was recorded in $\mathrm{T}_{10}$. These results are in accordance with Sharma (1995) in peach. Further, the results get support by Kaith et al., (2011) who reported leaf P content not so much influenced by pruning intensities in peach and the result of Khaosumain et al., (2013) who reported leap P content decrease with the increasing rate of $\mathrm{N}$ applied in longan.

As perusal of the data given in Table 2, different rejuvenation treatments had significant effect on per cent $\mathrm{K}$ content of leaf in pooled mean of 2011 to 2014. Maximum leaf $\mathrm{K}(2.58 \%)$ content was observed in $\mathrm{T}_{7}$ and minimum leaf $\mathrm{K}(2.06 \%)$ content was observed in $\mathrm{T}_{10}$. An antagonism effect between soil $\mathrm{N}$ and $\mathrm{K}$ has been observed and it might be the responsible for reduction in the uptake of $\mathrm{K}$ by the plants. The higher leaf $\mathrm{K}$ in the heavily pruned trees was due to the less accumulation of dry matter and vigorous growth which caused increased uptake of $\mathrm{K}$. Similar results have been observed in different cultivars of peach by Singh (1992) and Sharma (1995) and in sweet cherry by Fallahi et al., (1993). The observations are again supported by Kaith et al., (2011) who observed increase in leaf $\mathrm{K}$ content with increased pruning intensities in apple and by Khaosumain et al., (2013) who reported nitrogen treatments had no effect on leaf $\mathrm{K}$ concentration in longan.

Different treatments influenced the leaf $\mathrm{Ca}$ content significantly (Table 2). The increasing levels of pruning and nitrogen resulted in decreased of leaf $\mathrm{Ca}$ content in apricot. Highest leaf $\mathrm{Ca}(2.93 \%)$ content was recorded in $\mathrm{T}_{1}$. Whereas, the lowest leaf $\mathrm{Ca}(2.43 \%)$ content was observed in $\mathrm{T}_{9}$.

These results agree with the findings of Fallahi et al., (1993) in sweet cherry and in peach by Singh (1992) and Sharma (1995).

The decrease in leaf $\mathrm{Ca}$ content with increasing pruning intensity could be attributed to higher $\mathrm{K}$ levels in the leaves of heavily pruned trees. The higher amount of dry matter in the lightly pruned trees also favoured more $\mathrm{Ca}$ accumulation. Kaith et al., (2011) observed $\mathrm{Ca}$ concentration in leaves decreased with an increase in the pruning intensity. The failure of $\mathrm{N}$ application to increase $\mathrm{Ca}$ level in leaves may be related to the slow mobility of $\mathrm{Ca}$ in plant tissue.

Different treatment combinations had inconsistent influence on the leaf $\mathrm{Mg}$ content (Table 2). The maximum leaf $\mathrm{Mg}(0.82 \%)$ content was recorded in $\mathrm{T}_{1}$ and minimum $(0.46 \%)$ in $\mathrm{T}_{9}$. The results are on par with the findings of Singh (1992) and Sharma, (1995) who recorded higher leaf $\mathrm{Mg}$ content under light pruning intensity and lower levels of $\mathrm{N}$ and $\mathrm{K}$ fertilizers in peach. But, contrast results were found in apple from the studies of Kaith et al., (2011) and Guak et al., (2003).

\section{Effect on micro nutrient content of the leaf}

As perusal of the diagram in Figure 1 leaf Fe content of the apricot increased significantly with increasing severity of pruning and $\mathrm{N}$ levels. The maximum leaf Fe (226.82 ppm) content was recorded in $\mathrm{T}_{9}$ and minimum (170.04 ppm) in $\mathrm{T}_{10}$. The higher Fe in heavily pruned trees may be due to pruning effects on growth as heavy pruning induces vigorous growth that ultimately increases nutrient uptake through transpiration pull. 
Table.1 Physico-chemical properties of experimental orchards soil

\begin{tabular}{|c|c|c|c|}
\hline \multirow[t]{2}{*}{ SI. No } & Particulars & \multicolumn{2}{|c|}{ Results } \\
\hline & Mechanical analysis & 2011 & 2013 \\
\hline 1 & Bulk density $\left(\mathrm{Mg} / \mathrm{m}^{3}\right)$ & 1.24 & 1.26 \\
\hline \multirow[t]{2}{*}{2} & Field capacity & $28.0 \%$ & $28.08 \%$ \\
\hline & Chemical analysis & & \\
\hline 3 & $\mathrm{pH}$ & 6.62 & 6.60 \\
\hline 4 & Electrical conductivity $\left(\mathrm{dSm}^{-1}\right)$ & 0.42 & 0.44 \\
\hline 5 & Organic Carbon (\%) & $1.58 \%$ & $1.62 \%$ \\
\hline 6 & Available N (Kg/ha.) & 318.64 & 319.67 \\
\hline 7 & Available P (Kg/ha.) & 16.62 & 16.76 \\
\hline 8 & Available K (Kg/ha.) & 172 & 180 \\
\hline
\end{tabular}

Table.2 Effect of rejuvenation pruning and nitrogen levels on leaf macronutrient nutrient status of declining apricot

\begin{tabular}{|c|c|c|c|c|c|}
\hline \multirow[t]{2}{*}{ Treatments } & $\begin{array}{l}\text { Nitrogen } \\
(\%)\end{array}$ & $\begin{array}{c}\text { Phosphorus } \\
(\%)\end{array}$ & $\begin{array}{l}\text { Potassium } \\
(\%)\end{array}$ & $\begin{array}{l}\text { Calcium } \\
(\%)\end{array}$ & $\begin{array}{l}\text { Magnesium } \\
(\%)\end{array}$ \\
\hline & $\begin{array}{c}\text { Pooled } \\
\text { mean }(2011- \\
\text { 14) }\end{array}$ & $\begin{array}{c}\text { Pooled mean } \\
(2011-14)\end{array}$ & $\begin{array}{c}\text { Pooled mean } \\
(2011-14)\end{array}$ & $\begin{array}{c}\text { Pooled } \\
\text { mean }(2011- \\
14)\end{array}$ & $\begin{array}{c}\text { Pooled mean } \\
(2011-14)\end{array}$ \\
\hline $\mathbf{T}_{1}$ & 2.62 & 0.239 & 2.35 & 2.93 & 0.82 \\
\hline $\mathbf{T}_{2}$ & 2.67 & 0.232 & 2.25 & 2.84 & 0.77 \\
\hline $\mathbf{T}_{\mathbf{3}}$ & 2.73 & 0.230 & 2.10 & 2.79 & 0.74 \\
\hline $\mathbf{T}_{4}$ & 2.73 & 0.236 & 2.47 & 2.73 & 0.67 \\
\hline $\mathbf{T}_{5}$ & 2.77 & 0.234 & 2.37 & 2.66 & 0.63 \\
\hline $\mathrm{T}_{6}$ & 2.81 & 0.224 & 2.32 & 2.61 & 0.60 \\
\hline $\mathrm{T}_{7}$ & 2.78 & 0.215 & 2.58 & 2.54 & 0.53 \\
\hline $\mathbf{T}_{8}$ & 2.80 & 0.212 & 2.48 & 2.49 & 0.48 \\
\hline $\mathrm{T}_{9}$ & 2.89 & 0.210 & 2.42 & 2.43 & 0.46 \\
\hline $\mathrm{T}_{10}$ & 2.56 & 0.207 & 2.06 & 2.88 & 0.78 \\
\hline $\mathrm{SEm} \pm$ & 0.05 & 0.011 & 0.04 & 0.03 & 0.02 \\
\hline $\mathrm{CD}(\mathrm{p}=0.05)$ & 0.15 & 0.030 & 0.13 & 0.09 & NS \\
\hline
\end{tabular}


Fig.1 Effect of rejuvenation pruning and nitrogen levels on leaf micronutrient (Fe and $\mathrm{Mn}$ ) status of declining apricot

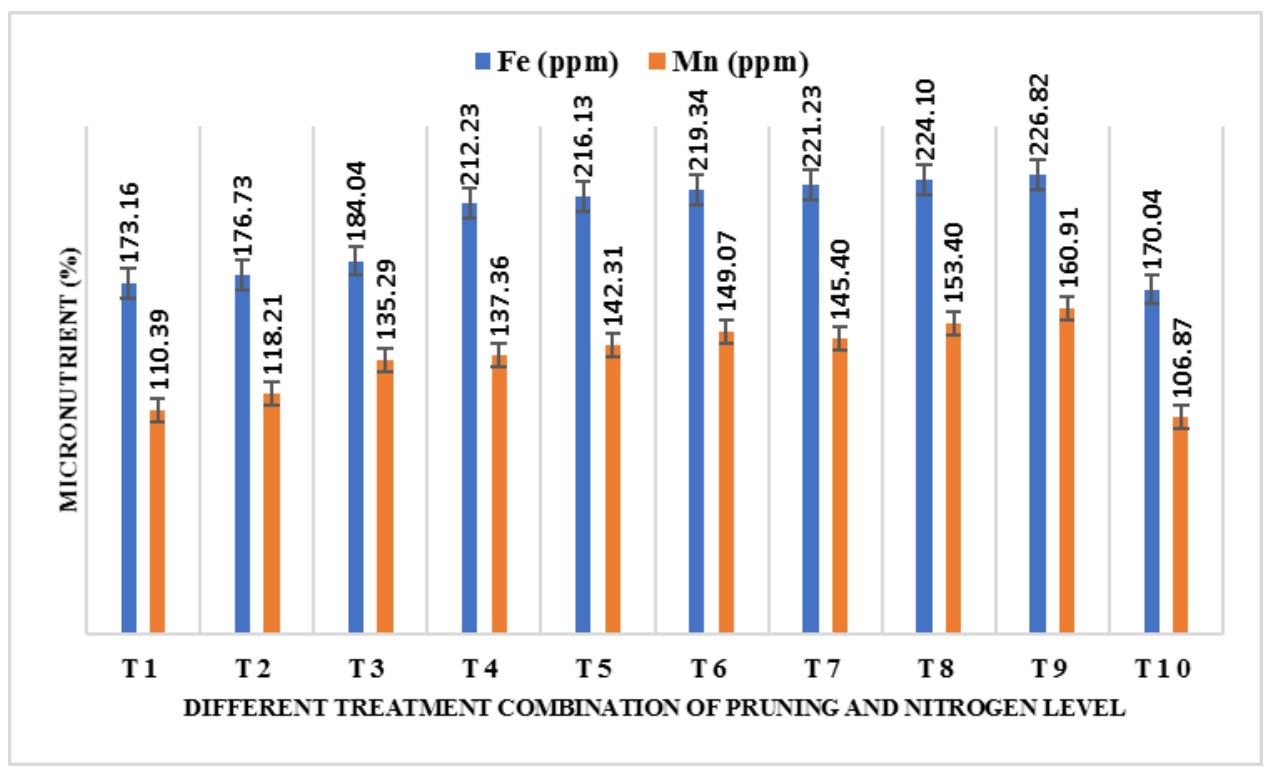

Fig.2 Effect of rejuvenation pruning and nitrogen levels on leaf micronutrient $(\mathrm{Zn}$ and $\mathrm{Cu})$ status of declining apricot

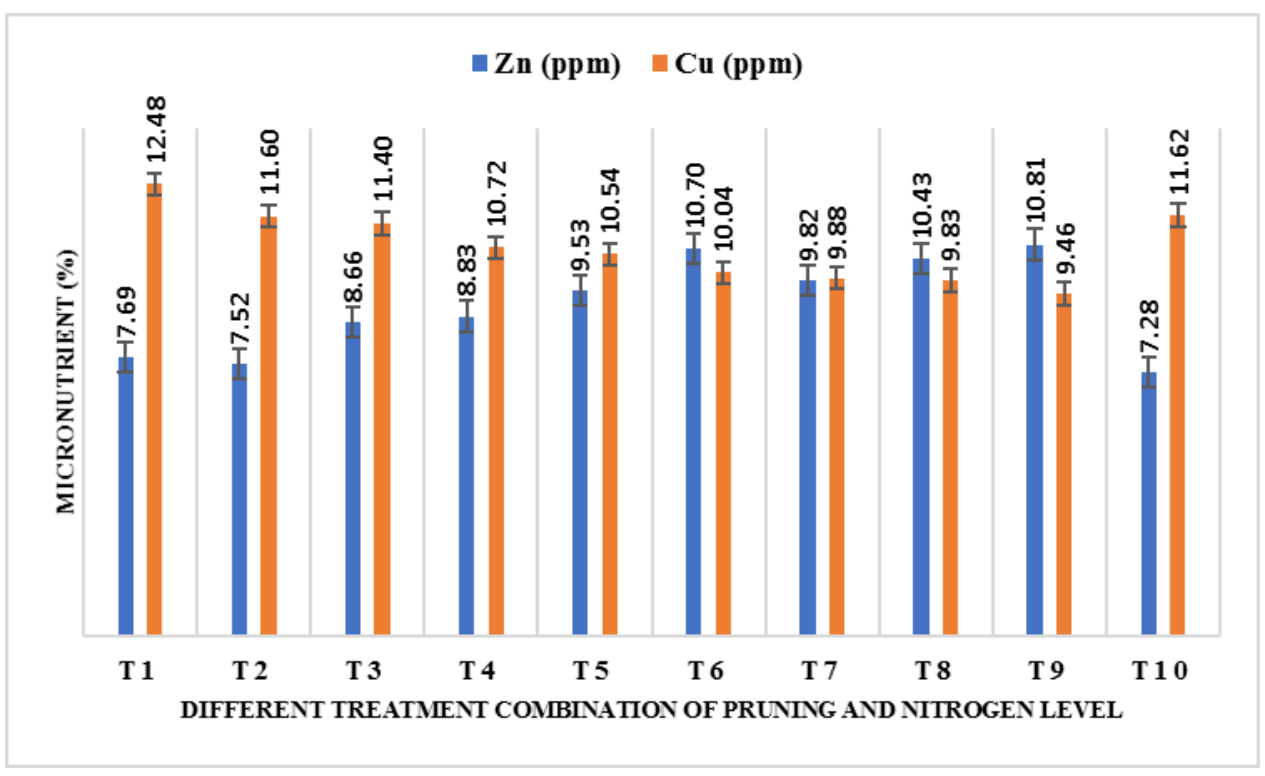

The results are in conformity with the findings of Suklabaidya (2012) who recorded high leaf Fe content under heavy pruning and higher levels of $\mathrm{N}$ in plum. These results again get supports by works of Fallahi et al., (1993) in sweet cheery and by works of Singh et al., (1997) and Sharma (1995) in peach.
The antagonistic effect of $\mathrm{P}$ and $\mathrm{Fe}$ in this study is in accordance with Hansen et al., (2006).

The increased severity of pruning and $\mathrm{N}$ levels increased leaf $\mathrm{Mn}$ content of apricot leaves (Figure 1). The higher leaf Mn (160.91 
ppm) content in $\mathrm{T}_{9}$ could be attributed to pruning effects on growth as heavy pruning induces vigorous growth. Higher leaf $\mathrm{Mn}$ in heavily pruned trees may also be due to synergistic effect of $\mathrm{N}$. The results are in line with the findings of Suklabaidya (2012), Singh et al., (1997), Sharma (1995) and Fallahi et al., (1993) who reported higher leaf Mn content under heavy pruning intensity and higher levels of $\mathrm{N}$ fertilizers.

The leaf $\mathrm{Zn}$ content was significantly affected by different pruning severities and $\mathrm{N}$ treatment combinations during the study (Figure 2). The leaf $\mathrm{Zn}$ content increased with increasing level of pruning and nitrogen. The higher leaf $\mathrm{Zn}(10.81 \mathrm{ppm})$ content in $\mathrm{T}_{9}$ could be attributed to pruning effects on growth, as heavy pruning induces vigorous growth, or it may be due to the antagonistic effect of $\mathrm{P}$ on the $\mathrm{Zn}$. These finding agree with Suklabaidya (2012) and Fallahi et al., (1993) who reported leaf $\mathrm{Zn}$ content increases with high pruning intensities and high nitrogen doses in plum and cherry respectively.

Significant reduction in the leaf $\mathrm{Cu}$ content was observed during the investigation with decrease levels of pruning and nitrogen (Figure 2). This could also be attributed to the negative correlation of $\mathrm{Cu}$ with $\mathrm{Zn}$ and $\mathrm{N}$. These finding agree with Suklabaidya (2012), Fallahi et al., (1993) and Singh et al., (1997) who observed decreased in leaf $\mathrm{Cu}$ content with increase in pruning intensities and nitrogen level in different temperate fruits.

\section{Effect on soil status of the orchard}

Post analysis of soil samples were done to compute the status of physico-chemical properties of soil of experimental orchards to verify the effect of treatments. The values recorded under Table 1 reveal that pruning and fertilization improved physico-chemical properties of the orchard soil. Increase in bulk density, field capacity, electrical conductivity, organic carbon and available $\mathrm{N}, \mathrm{P}, \mathrm{K}$ were observed, whereas the $\mathrm{pH}$ value was decrease. Reduction in soil $\mathrm{pH}$ seems to be associated with the application of ammonical form of nitrogen that creates acidic conditions in the soil. Higher electrical conductivity was the result of addition of more salts in the form of fertilizers like Urea, Single Super Phosphate and Muriate of Potash. Increase in organic carbon may be attributed to more favourable temperature condition with the consequent luxuriant vegetative growth and accumulation of organic matter when inorganic and organic fertilizers (FYM) were added to the soil. Increase in available $\mathrm{N}, \mathrm{P}, \mathrm{K}$ of the soil might be due to application of different $\mathrm{N}$ levels and standard recommended doses of FYM, P and $\mathrm{K}$. The findings are in conformity with Suklabaidya (2012).

Taking into consideration the means of pooled data of four-year study, it reveals that treatment combination of different pruning intensities and different nitrogen level affect the leaf and soil nutrient status of the old and senile apricot trees. The leaf $\mathrm{N}, \mathrm{Fe}, \mathrm{Mn}$ and $\mathrm{Zn}$ content increased with the heavy pruning treatment along with increasing levels of nitrogen, while leaf $\mathrm{P}, \mathrm{Ca}, \mathrm{Mg}$ and $\mathrm{Cu}$ content show declining trends with the increasing pruning severity and nitrogen levels. The results obtained here would be a valuable source and guideline for future investigations.

\section{References}

A.O.A.C. 1980. Official methods of analysis of association of analytical chemists, $13^{\text {th }}$ ed. (ed. W. Horowitz). Benjamin Franklin Station. Washington, D.C. p. 1018.

Ali, S., Masud, T. and Abbasi, K.S. 2011. Physico-chemical characteristics of apricot (Prunus armeniaca L.) grown in 
Northern Areas of Pakistan. Scientia Horticulture, 130(2): 386-392.

Anonymous. 2010. Annual Administrative Report. Department of Horticulture, Government of Himachal Pradesh, Shimla, 171002.

Cassman, K.G., Dobermann, A. and Walters, D.T., 2002. Agro-ecosystems $\mathrm{N}$ use efficiency and $\mathrm{N}$ management. Ambio. 31(2): 132-140.

Chapman, H.D. 1964. Suggested foliar sampling and handling techniques for determining the nutrient status of some field horticultural and plantation crops. Indian Journal of Horticulture, 21: 97119.

Cheng, L. and Raba, R. 2009. Accumulation of macro and micro- nutrients and nitrogen demand supply relationship of Gala/ Malling 26 apple trees grown in sand culture. Journal of American Society of Horticulture Science, 134 (1): 3-13.

David, D. J. 1960. The determination of exchangeable sodium, potassium, calcium and magnesium in soils by atomic-absorption spectrophotometry. Analyst, 85: 495-503.

Fallahi, E., Righetti, T.L. and Proebsting, E.L. 1993. Pruning and nitrogen effects on elemental partitioning and fruit maturity in 'Bing' sweet cherry. Journal of Plant Nutrition, 16(5): 753-763.

FAO. 2014. FAOSTAT. Online statistical database (retrieved November 2014) (available at http:// faostat.fao.org).

Fishman, M. J. 1966. The use of atomic absorption for analysis of natural waters. At. Abs. News. 1. 5: 102-106.

Gomez, K.A. and Gomez, A.A. 1984. Statistical procedures for agricultural research $\left(2^{\text {nd }}\right.$ ed.). John wiley and sons, New York, p. 680.

Guak. S., Neilson, D.P., Millard, R. and Neilsen, G.H. 2003. Determining the role of nitrogen remobilization for growth of apple trees. Journal of Experimental Botany, 54 (390): 21212131.

Hansen, N.C., Hopkins, B.G., Ellsworth, J.W. and Jolley, V.D. 2006. Iron nutrition in field crops. In: Barton, L.L., Abadía, J. (Eds.), Iron Nutrition in Plants and Rizhospheric Microorganisms. Springer, Dordrecht, pp. 23-59.

Jackson, M.L. 1967. Soil Chemical Analysis. Asia Publishing House, Bombay, $\mathrm{p}$ 498.

Jackson, M.L. 1973. Soil Chemical Analysis. Prentice hall, New Delhi. p. 120.

Kaith, N.S., Sharma, U., Sharma, D.D. and Mehta, D.K. 2011. Effect of different pruning intensities on growth, yield and leaf nutrients status of starking delicious apple in hilly region of Himachal Pradesh, Journal of Farm Sciences, 1(1):37-42

Kanwar, J.S. and Chopra, S.L. 1976. Agricultural chemistry. S. Chand and Co., Delhi. pp. 130-131.

Kenworthy, A.L. 1964. Fruit, nut and plantation crops, deciduous and evergreen: a guide for collecting foliar samples for nutrient elements analysis. Horticulture Department of Michigan State University, Mieneo pp. 1-39.

Khaosumain, Y., Sritontip, C. and Changjeraja, S. 2013. Effects of Difference Nitrogen Fertilizer Doses Growth, Leaf Nutrient Concentration, Flowering and Fruit Quality in OffSeason Longan. Acta Hort. (ISHS) 984: 271-274

Lee, S.K. and Kader, A.A. 2000. Pre-harvest and post-harvest factors influencing vitamin $\mathrm{C}$ content ofhorticultural crops. Postharvest Biology and Technology, 20: 207-220.

Merwin, H. D. and Peech, M. 1951. Exchangeability of soil potassium in the sand, silt and clay fractions as influenced by the nature of the 
complimentary exchangeable cation. Soil Sci. Soc. Amer. Proc. (1950) 15: 125-128.

Milosevic, T., Milosevic, N. and Glisic, I. 2013. Tree growth, yield, fruit quality attributes and leaf nutrient content of 'Roxana' apricot as influenced by natural zeolite, organic and inorganic fertilisers. Scientia Horticulturae, 156: 131-139.

Milosevic, T., Milosevic, N., 2013. Response of young apricot trees to natural zeolite, organic and inorganic fertilisers. Plant Soil Environ. 59: 44-49.

Munzuroglu, O., Karatas, F. and Geckil, H. 2003. The vitamin and selenium contents of apricot fruit of different varieties cultivated in different geographical regions. Food Chemistry, 83: 205-212.

Naik, M.H. and Babu, R.S.H. 2005. Feasibility of organic farming in guava. 1st International Guava Symposium, Central Institute for Subtropical Horticulture, Lucknow. p 69.

Olsen, S.R., Cole, C.V., Watanabe, F.S. and Dean, L.A. 1954. Estimation of available phosphorus by extraction with sodium bicarbonate. U. S. Dept Agri. Circ., 939.

Sharma, D.P. 1995. Effect of pruning intensities under different levels of nitrogen and potassium on growth, yield and quality of peach (Prunus persica Batsch) cv, July Elberta. Ph. D. Thesis,
Dr. Y.S. Parmar University of Horticultuer and Forestry, Solan, India.

Singh, D. 1992. Effect of pruning intensities under different levels of nitrogen on growth, yield and quality of peach cv. July Elberta. Ph.D. Thesis, Dr. Y. S. Parmar University of Horticulture and Forestry, Solan (H. P) India.

Singh, D., Chauhan, J.S. and Kainth, N.S. 1997. Pruning in peach: A review. Agriculturae Reviews (Karnal), 18(3/4): $147-154$.

Subbaiah, B.V. and Asija, G.L. 1956. A rapid procedure for the determination of available nitrogen in soils. Current Science, 25: 259-260.

Sud, G. and Bhutani, V.P., 1994. Effects of autumn sprays of urea on the nutrient status of apricot. Hortic. J., 7: 83-88.

Suklabaidya, A. 2012. Effect of orchard management practices on growth, fruiting and yield of senile plum trees. Ph.d. Thesis, Dr. Y.S. Parmar University of Horticulture and Forestry, Nauni, Solan (H. P), India.

USDA. United States Department of Agriculture, National Nutrient Database; Nutrition facts and information for apricots, raw. Retrieved from; http://www.nutritiondata.com. 2005. Accessed on 2-11-2012.

Walkley and Black. 1934. Rapid titration method of organic carbon in soil. Current Science, 26: 319-322.

\section{How to cite this article:}

Thokchom, R., D.P. Sharma and Thakur, K.K. 2018. Effect of Rejuvenation Pruning and Nitrogen Levels on Leaf Nutrient Status of Old and Senile Apricot (Prunus armeniaca L.) cv. New Castle Trees. Int.J.Curr.Microbiol.App.Sci. 7(01): 2492-2500. doi: https://doi.org/10.20546/ijcmas.2018.701.299 